\title{
CATALASE ACTIVITY IN THE DEVELOPING RABBIT TESTIS
}

\author{
T. J. IHRIG, R. H. RENSTON, J. P. RENSTON AND B. GONDOS \\ Department of Pathology, University of California, \\ San Francisco, California 94143, U.S.A.
}

(Received 3rd December 1973)

Increasing evidence suggests that catalase may be an important enzyme in the metabolism of lipids, especially cholesterol (Caravaca \& May, 1964; Caravaca \& Dimond, 1967; Cuadrado \& Bricker, 1973), and may function with other peroxisomal enzymes in steroidogenesis (Black \& Bogart, 1973). Catalase-bearing peroxisomes have been described in Leydig cells of the rodent testis (Reddy \& Svoboda, 1972). Maturation of the testis is known to be associated with changes in testicular lipids (Davis, Bridges \& Coniglio, 1966; Oshima \& Carpenter, 1968; Ichihara, 1969) and testosterone (Lipsett \& Tullner, 1965; Warren, Haltmeyer \& Eik-Nes, 1973), but there has been no information on testicular catalase activity changes with age. The present report describes the level of catalase in the prepubertal and mature rabbit testis, and correlates the findings with morphological changes during testicular development.

Hepatic and testicular samples were obtained at approximately 30-day intervals from New Zealand white bucks ranging from 30 to 250 days of age. Rabbits were anaesthetized by intravenous administration of sodium pentobarbital. Tissues were removed and placed in ice-cold isolation medium consisting of $0.15 \mathrm{M}-\mathrm{NaCl}$ and $0.01 \mathrm{M}$-sodium phosphate buffer, $\mathrm{pH} \mathrm{7.4.} \mathrm{After} \mathrm{removal} \mathrm{of}$ the tunica from the testis, tissues were weighed, homogenized in $10 \mathrm{vols}$ of buffer using a glass-Teflon homogenizer (A. H. Thomas \& Co.), and spun at $700 \mathrm{~g}$ in a Sorvall RC-2B centrifuge with SS-34 rotor for $10 \mathrm{~min}$ at $4^{\circ} \mathrm{C}$.

The supernatants were assayed for catalase activity according to the procedure of Cohen, Dembiec \& Mareus (1970), using the reduction of potassium permanganate by excess hydrogen peroxide. The colour due to remaining potassium permanganate was measured at $480 \mathrm{~nm}$ using a Gilford microsample spectrophotometer, model N-300, with a flow-through cuvette. Enzyme activity levels in heated samples were subtracted from all values.

Protein concentrations of homogenates were determined by the method of Lowry, Rosebrough, Farr \& Randall (1951) using a bovine serum albumin standard (Armour Pharmaceutical Co.). One enzyme unit was defined as the amount of enzyme necessary to utilize half of the hydrogen peroxide substrate $(6 \mathrm{~mm})$ in $1 \mathrm{~min}$ at $0^{\circ} \mathrm{C}$. Specific activities were calculated on the basis of both gram wet weight and milligrams of protein per assay.

The catalase-specific activity of the testis showed a slight but significant drop from 30 to 64 days, with a sharp eightfold drop from 64 to 101 days (Text-fig. 1). 


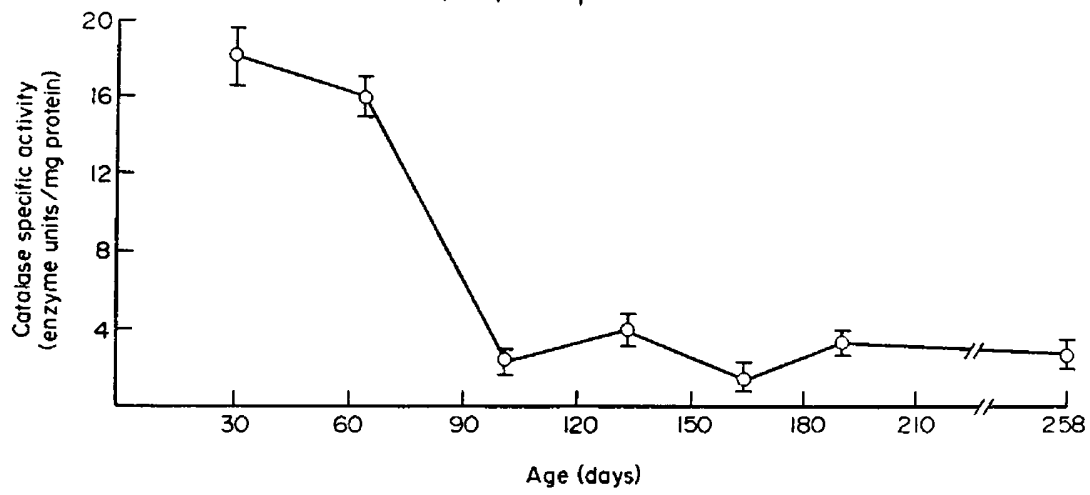

TexT-FIG. 1. Testicular catalase-specific activity correlated with age and stages of testicular germ cell maturation in rabbits.

This was followed by a slight rise at 133 days. The curve dropped to its lowest point at 163 days and reached a slightly higher plateau at 190 days, continuing to 250 days with no significant change. Enzyme-specific activity values calculated on the basis of gram wet weight and milligrams of protein showed identical changes. Liver values of catalase-specific activity showed no statistical change from 64 to 101 days and increased from 101 to 134 days (Table 1). At 60 days of age, liver values were about ten times higher than those of the testis. Protein values of hepatic and testicular homogenates were essentially unchanged throughout the period tested.

The most significant feature of the relationship of catalase activity and maturation in the testis was an eightfold drop in catalase activity between 64 and 101 days. The total weight of the testis during this period increased only three fold. The decrease in catalase-specific activity cannot, therefore, be explained solely by a change in testicular weight, even if total catalase activity remained constant during this growth period.

Table 1. Comparison of testicular and hepatic catalase levels with age in rabbits

\begin{tabular}{c|c|c|c|c|c}
\hline $\begin{array}{c}\text { Age } \\
\text { (days) }\end{array}$ & $\begin{array}{c}\text { No. of } \\
\text { animals }\end{array}$ & $\begin{array}{c}\text { Rabbit } \\
\text { weight }\end{array}$ & $\begin{array}{c}\text { Testis } \\
\text { weight }\end{array}$ & $\begin{array}{c}\text { Catalase sp. act. } \\
\text { (testis) }\end{array}$ & $\begin{array}{c}\text { Catalase sp. act. } \\
\text { (liver) }\end{array}$ \\
\hline $30 \pm 0.5$ & 7 & $619 \pm 16$ & $0 \cdot 043 \pm 0 \cdot 01$ & $18 \cdot 5 \pm 1 \cdot 5$ & $209 \cdot 0 \pm 13 \cdot 2$ \\
$64 \pm 1 \cdot 1$ & 5 & $1712 \pm 80$ & $0 \cdot 410 \pm 0.08$ & $16 \cdot 0 \pm 1 \cdot 0$ & $154 \cdot 3 \pm 25 \cdot 0$ \\
$101 \pm 0 \cdot 4$ & 6 & $2319 \pm 73$ & $1 \cdot 240 \pm 0 \cdot 18$ & $2 \cdot 3 \pm 0 \cdot 4$ & $142 \cdot 9 \pm 8 \cdot 3$ \\
$133 \pm 1 \cdot 3$ & 6 & $2870 \pm 118$ & $2 \cdot 030 \pm 0 \cdot 19$ & $3 \cdot 9 \pm 0 \cdot 8$ & $216 \cdot 8 \pm 15 \cdot 5$ \\
$164 \pm 1 \cdot 4$ & 5 & $2724 \pm 102$ & $2 \cdot 420 \pm 0 \cdot 29$ & $1 \cdot 4 \pm 0 \cdot 6$ & $216 \cdot 3 \pm 18 \cdot 1$ \\
$191 \pm 3 \cdot 0$ & 5 & $2905 \pm 192$ & $2 \cdot 690 \pm 0 \cdot 23$ & $3 \cdot 2 \pm 0 \cdot 4$ & $215 \cdot 0 \pm 18 \cdot 2$ \\
$258 \pm 3 \cdot 8$ & 4 & $2888 \pm 159$ & $3 \cdot 030 \pm 0.39$ & $2 \cdot 7 \pm 0 \cdot 6$ & $192 \cdot 9 \pm 14 \cdot 2$ \\
\hline
\end{tabular}

Rabbit and testis weights are in grams, and enzyme specific activities are in enzyme units per mg protein. A.ll values given are the mean \pm S.E.M. 
From previous work on the rabbit testis (Gondos, Renston \& Conner, 1973), it is known that spermatogonia first appear in the testicular tubules at 7 to 8 weeks of age, spermatocytes at 9 weeks, spermatids at 12 weeks, and spermatozoa at 14 weeks. Motile spermatozoa appear in the ejaculate at about 4 months (Hafez, 1970). The period during which the observed sharp drop in catalase activity occurred corresponded with the onset of the initial prepubertal spermatogenic cycle, including the period of spermiogenesis (Text-fig. 1). This is also the time when Leydig cell maturation is completed (Gondos \& Conner, 1972), suggesting a possible relationship between testosterone and catalase activity. It is of interest in this regard that the level of testosterone synthesis early in post-natal rabbit development is much lower than in the late fetal or post-pubertal period (Lipsett \& Tullner, 1965).

Also noteworthy is the correlation between the level of catalase activity and the relative number of Sertoli cells present. Sertoli cell maturation is completed during early post-natal development before the onset of spermatogenesis (Gondos et al., 1973). The proportion of Sertoli cells during the prespermatogenic period is high, germinal cells representing only a small percentage of the total cell population in the developing seminiferous tubules. Once spermatogenesis begins, there is a marked increase in germinal cells, reflected in the increasing weight of the testis; the number of Sertoli cells remains the same and thus their relative concentration declines. It could be significant that the fall in catalase activity during the initial spermatogenic cycle directly parallels the decline in Sertoli cell concentration.

This work was supported in part by a grant from the U.S. Public Health Service (HD-08202).

\section{REFERENGES}

Black, V. H. \& Bogart, B. I. (1973) Peroxisomes in inner adrenocortical cells of fetal and adult guinea pigs. F. Cell Biol. 57, 345.

Caravaca, J. \& Dimond, E. G. (1967) Prevention of induced atherosclerosis by peroxidase. Science, N.Y. 155, 1284.

Caravaca, J. \& May, M. D. (1964) The isolation and properties of an active peroxidase from hepatocatalase. Biochem. biophys. Res. Commun. 16, 528.

Cohen, G., Dembiec, D. \& Mareus, J. (1970) Measurement of catalase activity in tissue extracts. Analyt. Biochem. 34, 30.

Cuadrado, R. R. \& Bricker, L. A. (1973) An abnormality of hepatic lipogenesis in a mutant strain of acatalasemic mice. Biochim. biophys. Acta, 306, 168.

DAvis, J. T., Bridges, R. B. \& Coniglio, J. G. (1966) Changes in lipid composition of the maturing rat testis. Biochem. . . 98, 342.

Gondos, B. \& CoNNER, L. A. (1972) Ultrastructural differentiation of interstitial cells in the fetal and postnatal rabbit testis. Biol. Reprod. 7, 118.

Gondos, B., Renston, R. H. \& Conner, L. A. (1973) Ultrastructure of germ cells and Sertoli cells in the postnatal rabbit testis. Am. F. Anat. 136, 427.

Hafez, E. S. E. (1970) Rabbits. In Reproduction and Breeding Techniques for Laboratory Animals, Chap. 16. Ed. E. S. E. Hafez. Lea \& Febiger, Philadelphia.

IchiHARA, I. (1969) Cholesterol changes in developing testicular interstitial cells of the mouse: histochemical and biochemical study. Anat. Rec. 163, 595.

Lipsett, M. D. \& Tullner, W. W. (1965) Testosterone synthesis by the fetal rabbit gonad. Endocrinology, 77, 273.

Lowry, O. H., Rosebrough, N. J., FARR, A. L. \& Randall, R. J. (1951) Protein measurement with the Folin phenol reagent. F. biol. Chem. 193, 265. 
Oshima, M. \& Carpenter, M. P. (1968) The lipid composition of the prepubertal and adult rat testis. Biochim. biophys. Acta, 152, 479.

REDDY, J. \& SvoBODA, D. (1972) Microbodies (peroxisomes) in the interstitial cells of rodent testes. Lab. Invest. 26, 657.

Warren, D. W., Halmmeyer, G. G. \& Eik-Nes, K. B. (1973) Testosterone in the fetal rat testis. Biol. Reprod. 8, 560. 